\title{
'That's the problem with that lake; it changes sides': mapping extraction and ecological exhaustion in the Atacama
}

\author{
Sally Babidge ${ }^{1}$ \\ Fernanda Kalazich \\ Manuel Prieto \\ Karina Yager \\ The University of Queensland, Australia \\ Universidad Catolica del Norte, Chile \\ State University of New York, Stony Brook, USA
}

\begin{abstract}
Multiple dynamics produce the ecological present. For the past 30 years or more, in the southern Atacama salt pan (Salar) in northern Chile, extractive industries have been accumulating minerals and water in exhaustive quantities, taking ever more than may be regenerated. However, the exhaustion of the Salar de Atacama involves a more complex set of symptoms than demonstrable environmental depletion. Fragmented scientific knowledge of the salt pan due to the privatization of water and under-regulation of mining provides a partial explanation for this complexity. In this article, we discuss these political conditions of environmental knowledge and, using a range of methodologies, we show that the scale of resource extraction threatens social and environmental harm and exhaustion may manifest in unexpected ways. We used remote sensing data to elaborate maps that reflect environmental change (1985-2017), relative to the intensification of extractive activity for copper and lithium salts in the area. Using these data, we undertook ethnographic and participatory mapping work to discuss with people from the Peine Indigenous community how they have experienced ecological change related to mineral and water extraction in the southern Salar. A review of the historical and archaeological material helps us to show the depth of Indigenous people's relationships to and knowledge of the salt pan and surrounds, and how social memory may be ecological. Combining the different results of our research, we argue that ecological exhaustion emerges from social, environmental and political conditions driven by both tangible and uncertain impacts of industrial extraction. Revealing these conditions of exhaustion raises key questions about the complexity of the effects of extraction.
\end{abstract}

Keywords: Indigenous peoples; Salar de Atacama; participatory mapping; mining; water rights

\section{Résumé}

De multiples dynamiques produisent le présent écologique. Au cours des 30 dernières années, les industries extractives situées dans le sud du Salar d'Atacama, dans le nord du Chili, ont accumulé des minéraux et extrait de l'eau en quantités supérieures à leur capacité de régénération. Cependant, l'appauvrissement du Salar de Atacama comprend un ensemble de symptômes plus complexes que la simple démonstration de la dégradation de l'environnement. La fragmentation des connaissances scientifiques sur le salar, due à la privatisation de l'eau et à la faible réglementation de l'exploitation minière, explique en partie cette complexité. Dans cet article, nous discutons de ces conditions politiques de la connaissance de l'environnement. En utilisant une gamme de méthodologies, nous montrons que l'ampleur de l'extraction des ressources constitue une menace pour le tissu

\footnotetext{
${ }^{1}$ Dr. Sally Babidge, Anthropology, School of Social Science, The University of Queensland, St. Lucia 4072, Australia. s.babidge "at" uq.edu.au. Dr. Fernanda Kalazich and Dr. Manuel Prieto, Institute of Archaeology and Anthropology, Universidad Catolica del Norte, Le Paige 380, San Pedro de Atacama, Chile. fernanda.kalazich "at" ucn.cl, mprieto "at" ucn.cl. Dr. Karina Yager, Sustainability Studies, School of Marine and Atmospheric Sciences, Stony Brook University, New York. karina.yager "at" stonbrook.edu. Acknowledgements: Thankyou to Gino Sandoval, Bryan Gray, Daniela Muñoz, the Community of Peine, CONICYT Chile (PAI-MEC 80160087), Fondecyt (1160848 \& 11150130), CIIR, FONDAP (15110006), CNIA (Conv.2016, Folio79160085), the School of Social Science at University of Queensland, and referees.
} 
social et que les dommages et l'épuisement environnementaux peuvent se manifester de manière inattendue. Nous utilisons la télédétection pour préparer des cartes reflétant les changements environnementaux au fil du temps (1985-2017), liées à l'intensification de l'activité d'extraction du cuivre et du lithium dans la région. Sur la base de ces informations, nous avons effectué une ethnographie et une cartographie participative afin de discuter avec les membres de la communauté Indigène de Peine de leurs expériences concernant les changements écologiques liés à l'extraction de minéraux et d'eau dans le sud du salar. Une analyse des archives historiques et archéologiques a également contribué à rendre compte de la profondeur des relations et des connaissances des membres de la communauté sur le salar et ses environs et sur la manière dont la mémoire sociale peut aussi être écologique. En combinant les différents résultats de nos recherches, nous proposons que l'épuisement écologique résulte de conditions sociales, environnementales et politiques découlant d'impacts à la fois évidents et incertains de l'extraction industrielle. Révéler ces conditions d'épuisement soulève des questions essentielles sur la complexité des effets de l'extraction.

Mots-clés: Peuples indigènes; Salar d'Atacama; cartographie participative; l'exploitation minière; droits d'utilisation de l'eau

\section{Resumen}

Son múltiples las dinámicas que producen el presente ecológico. En los últimos 30 años, las industrias extractivas ubicadas en el sur del Salar de Atacama en el norte de Chile, han acumulado minerales y extraído agua en cantidades superiores a la capacidad de regeneración. Sin embargo, el agotamiento del Salar de Atacama comprende un conjunto de síntomas más complejo que la mera demostración del desgaste ambiental. La fragmentación del conocimiento científico del salar, debido a la privatización del agua y escasa regulación de la minería explican parcialmente esta complejidad. En este artículo, discutimos dichas condiciones políticas del conocimiento ambiental. Utilizando una gama de metodologías, mostramos que la escala de la extracción de recursos constituye una amenaza para el tejido social, y que el daño y agotamiento ambiental puede manifestarse de formas inesperadas. Utilizamos detección remota para elaborar mapas que reflejaran los cambios ambientales en el tiempo (1985-2017), relativos a la intensificación de la actividad extractiva de cobre y litio en el área. Sobre la base de esta información, realizamos etnografía y cartografía participativa para discutir con miembros de la Comunidad Indígena de Peine sus experiencias en torno al cambio ecológico relacionado con la extracción mineral e hídrica en el sur del salar. Una revisión del registro histórico y arqueológico contribuyó a su vez a dar cuenta de la profundida de las relaciones y conocimiento que los miembros de la comunidad tienen del salar y sus alrededores, y de cómo la memoria social puede ser también ecológica. Combinando los distintos resultados de nuestra investigación, planteamos que el agotamiento ecológico es resultado de condiciones sociales, ambientales y políticas derivadas tanto de impactos evidentes como inciertos de la extracción industrial. Revelar dichas condiciones del agotamiento plantea preguntas clave sobre la complejidad de los efectos de la extracción.

Palabras claves: Pueblos indígenas; Salar de Atacama; cartografías participativas; minería; derechos de agua

\section{Introduction}

Tilopozo, on the southern end of the Atacama Salt pan, northern Chile, is an azonal humid vegetation system -locally known as vega- with two main freshwater spring pools or ojos de agua surrounded by pasturelands, in the recognized territory of the Peine Indigenous Atacameño/Likan Antai Community (Figure 1). Nearby and part of Tilopozo's cultural landscape is the agricultural oasis of Tilomonte, fed by water from the Tulan canyon, dry pasturelands on the edge of the salt pan at Tilocalar, and a number of salt water lakes (lagunas) stretched across the otherwise dry surface of this territory. Members of the Peine Indigenous Community and their forebears have always relied on this area for winter pasture, collection of wild foods, salt and other products, and more recently also for recreation and possible tourism businesses. Tilopozo and the southern Salar are part of their home and ancestral territories. There are currently two mines that rely on aquifers in the southern Salar to process copper which are seeking to renew water extraction licenses in the next year or two, and with the growth of the lithium industry, the southern Salar is under mounting ecological and political pressure. With people's shift from long range and seasonal pastoralism beginning in the mid $20^{\text {th }}$ century (which had halted by the 1980s), to a varied economy of cash income from the mining industry and subsistence 
agriculture, the cultural landscape of the southern Salar has become something of a symbol of the community's endurance of, and sometime resistance to, the extraction industry.

Ecological threats to the southern Atacama salt pan ('the Salar') have become a focus in the regional and national popular press, and protective legislation has recently been introduced. In 2007, the water that lies beneath Tilopozo was named a protected aquifer by the Dirección General de Aguas² (DGA 425/2007). Further, one recent report in the national conservative broadsheet claimed that the DGA now considered this area "exhausted" (Vergara 2018: 14) and thus closed to any further requests for water concessions by industry. Growing concerns about the impact of the two corporate interests in lithium and active freshwater extraction infrastructure of the highest producing copper mine in the world, Minera Escondida, and its neighbor, Compañía Minera Zaldívar (CMZ), have led Chilean authorities to acknowledge the 'over exploitation' of the Salar's basin (in terms of large rights to extract versus low natural recharge rates). However, prior research reveals a combination of geophysical, material and political-economic factors that produce considerable ambiguity about the environmental effects of water extraction for copper on the southern Salar (Babidge 2019). As studies of wetlands in desert areas have shown, a closer examination of the human-natural intersections occurring at these places are critical to understanding how climate change affects arid zones in various parts of the world (Box et al. 2008). With increasing water extraction associated with the growing extractive industry for lithium salts operating on the Salar, understanding the nature of extractive impacts is becoming urgent.

There are multidimensional political and ecological pressures on the southern Salar de Atacama. These include the fact that it is a remote arid zone characterized by extremely low rainfall (average below $45 \mathrm{~mm}$ per year) with rare surface water, as well as a diminished intensity of use by indigenous peoples over the past fifty years. Its underground aquifers are the main source of water utilized for industrial (mining) processes. Since the mid-1980s we can characterize it as an intensive extractive zone, but there have been few robust independent ecological, hydrological and other environmental impact studies and few detailed considerations of the social effects of mining. The Chilean state has had weak regulatory power in terms of mitigating environmental and social impacts of extraction, and water extraction governance has been a well-identified problem in Chile for some time (Bauer 1998, 2004; Budds 2010; Carruthers 2001; Madaleno and Gurovich 2007; Prieto 2015, 2016). We contribute to these dimensions of the research problem by considering climatic data, satellite image analysis and local perceptions, observations, and explanations about socioecological transformations experienced in the area. We argue that the area is characterized by multifaceted forms of exhaustion.

Below, we discuss the conditions of exhaustion as revealed in the data generated through historical, and ethnographic inquiry and a participatory mapping workshop. In regard to the latter, in 2017 we produced a sequence of maps using satellite images (from 1985 to 2017) and used these in discussions with people from the Indigenous Community of Peine about their experience of extraction and environmental change. Landcover change analysis is often applied to discern loss of vegetation and changes in the physical landscape on a regional scale. In this case, maps of landcover change were applied as an ethnographic tool to elicit and identify people's perspectives of landscape change processes and the ways in which landscape change may be tied to local sociocultural processes and political or economic institutions.

Viewing the satellite images, the maps we generated showed no radical change in available vegetation cover over the period of study, yet there was some apparent increased surface water since 2010. The images (as maps, see Figures 2, 3, 4) served as a visual reference of landscape. They were used in a participatory mapping exercise with members of the Indigenous Community of Peine to prompt local experience and memory regarding social, political and environmental aspects of landscape change. We describe and discuss the results of the workshop below. In brief, these results support existing knowledge about multifaceted dimensions of social and environmental change resulting from industrial extraction in this area, that is; while it may be difficult to discern ecological impact in this area, various actors describe the effects of extraction in terms of exhaustion. Furthermore, participatory mapping discussions raised some unexpected peculiarities; without definitive reference to the maps, people spoke about surface waters that have moved around and salt lakes that have changed their shape. Lacking scientific explanation of these peculiarities, we argue that these unorthodox phenomena may assist in raising key questions about the complexities of ecological systems (Cruikshank 2005,

\footnotetext{
${ }^{2}$ General Water Directorate, hereafter DGA.
} 
2012; Yager 2015). The results of the mapping exercise deepen our appreciation of the multiple factors of ecological exhaustion in the southern Salar.

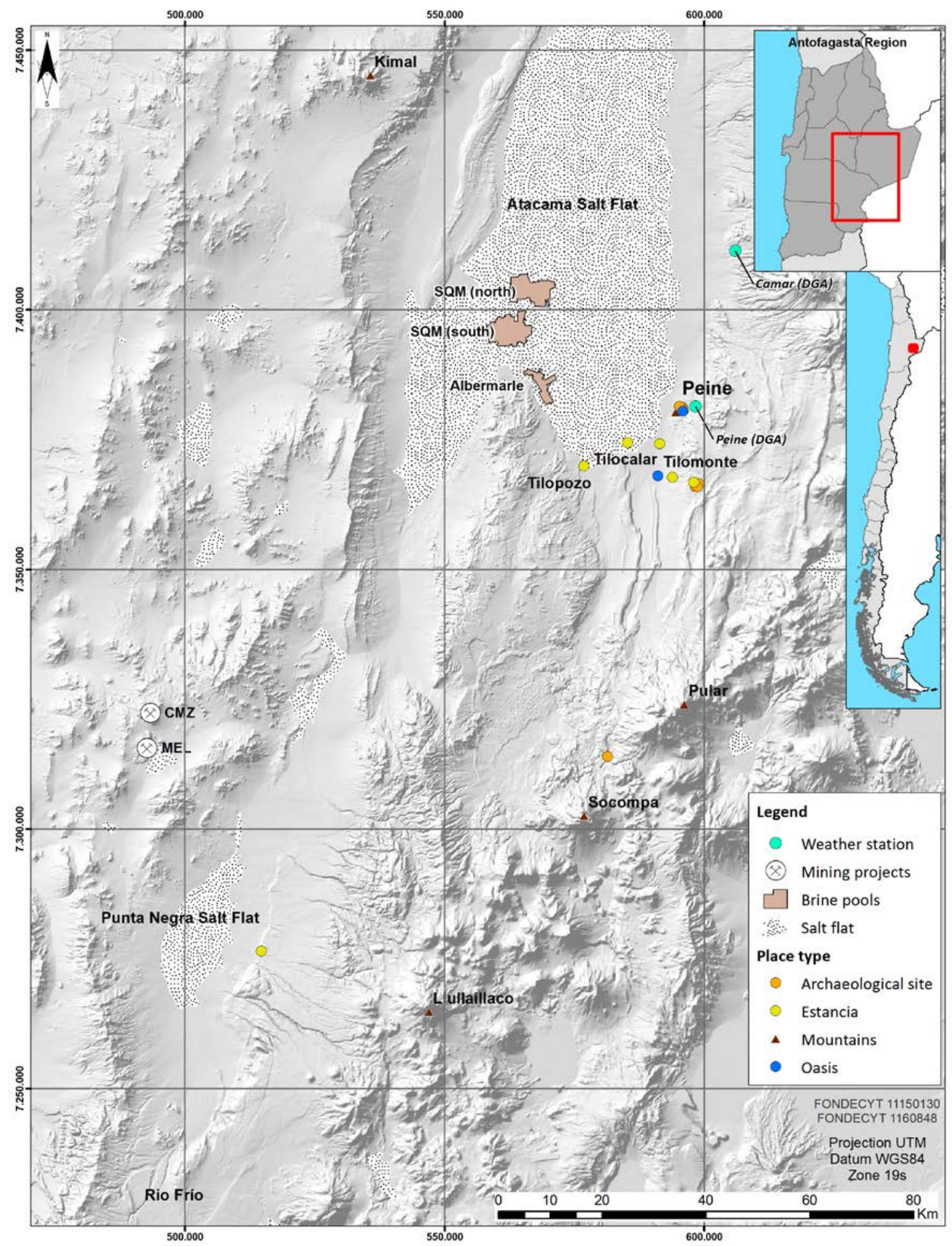

Figure 1: Study location. 
We start by explaining what we mean by ecological exhaustion. We then provide some background to Tilopozo and the southern Salar more generally as a place deeply known by the Peine Indigenous Community, relying on archaeological records and ethnographic material. People's depth of knowledge and oral testimony of their experience becomes a focus of the material we present from the participatory mapping exercise. Finally, we critically analyze the picture of ecological complexity and impact sketched out in this article, and propose ways that this complexity may be better understood.

\section{Ecologies of exhaustion}

Beyond the mere conception of the ecological impacts of human activity on natural environments, we have growing empirical evidence about the ways in which 'nature' and 'culture' are entwined agents in the making of ecologies (Fairhead and Leach 1996; Head 2017; Posey 1985), and how nature and political and economic processes are enmeshed through time (Blaikie 1985; Blaikie and Brookfield 1987; Robbins 2011; Watts 1983). Recent discussions of environmental change and the effects resulting from extraction incorporate this broader understanding of ecology as an entanglement of nature, culture, and political economy (e.g. Bebbington 2013; Jacka 2015). Understanding ecology in this way requires engaging with biophysical evidence alongside discourses that arise from a qualitative and experiential understanding of the environment (Forsyth 2002; Head 2017; Lave 2018). In extractive landscapes, there is a need to pair knowledge of environmental change with the political changes associated with the influences of that industry (Bebbington and Huber 2017; Frederiksen 2019). Environments are bundles of processes and things that may be analyzed as changing according to what Murray Li refers to as 'conjunctures' (2014: 4): the historical sets of connections across material, sociocultural and political economic dynamics. These approaches to ecological analysis entail understanding complexity through the ways in which relations and things come together through time and are associated with deep histories of the way capital is implicated in environmental change (see also Kloppenburg 1988; Moore 2017; Morrison 2018; Robbins 2011). In this article, we examine environmental change and its multiple and interconnected generators and consequences, with particular focus on the effects of the extractive industry. We consider the ways in which multiple dynamics lead to an ecological present, in this case the conditions of ecological exhaustion.

The main characteristic of extractive industries is the objective of making a profit from the exploitation of the environment through isolating material properties of ecologies into sets of natural resources in order to extract them (Boyd et al. 2001). The mining industry, for example, demands the literal extraction of landscape (including earth and water) for refining valued materials from the earth (Bridge 2004). When extractive industries physically modify the landscape in a way that passes thresholds of regeneration, replenishment or recovery, the reproduction of nature is no longer possible. This is when exhaustion occurs (Toscano 2018). We outline below the dynamics of extraction in the Salar de Atacama that have led to it being described as exhausted, and begin to build a picture of the particular conditions of ecological exhaustion there.

The state and the extraction industry are implicated in ecological exhaustion of the Salar in ways that have made environmental impact difficult to pinpoint. We note that the spatial effects of the activities of extraction companies in the Salar echo Ferguson's critique of oil companies in southern Africa (2005). That is, unlike the state's urge to 'see', simplify, regularize, and know territory (Scott 1998), extractive corporations have structural effects that include enhancing disorder through the processes in which capital interests are territorialized. Through company retention of data, private ownership of the resources (minerals and water) and enclosure of mined territory, ecologies are difficult to understand as wholes. The historical growth of capital and related accumulation of territory, resources, and water begin to describe the political dimensions of ecological exhaustion in the Salar.

Under the Pinochet dictatorship (1973-1990), national water resources were privatized under the Water Code (1981) and its intersection with the Mining Code (1982) significantly encouraged foreign investment resource extraction in Chile. In the northern arid regions, this meant increasing capital interests in copper and later brine extraction (for both producing potassium and lithium), coupled with interests in the accumulation of rights to extract water to process the minerals. The Anglo-Australian multinational, BHP took over operation at Minera Escondida Limitada (MEL) and began copper mining in 1990 (and remains the majority owner and operator of the mine). The immediately adjacent Compañía Minera Zaldivar (CMZ, now owned by Antofagasta Minerals) began extraction of copper and associated water rights accumulation in the Salar in the mid-1990s. 
Some years earlier, the Chilean Corporación de Fomento de la Producción (CORFO) ${ }^{3}$ began exploration work on the Salar, taking samples and excavating experimental evaporation ponds. In 1984, CORFO in partnership with 'Foote Minerals' began brine exploitation on the Salar (and at this time hired around 30 men from Peine). After passing through various stages of ownership, the mine is presently owned and operated by the North American company Albermarle. To the immediate north of Albermarle on the Salar is the SQM plant, which began extraction of brine for fertilizer products in 1995 and lithium by 1997, quickly increasing its production to become the highest global producer of this chemical with an extraction operation of much greater scale than its neighbor (see, for example Figure 2). As in the case of the Albermarle plant, many local men and some women from the Salar communities sought employment or contract work with SQM.

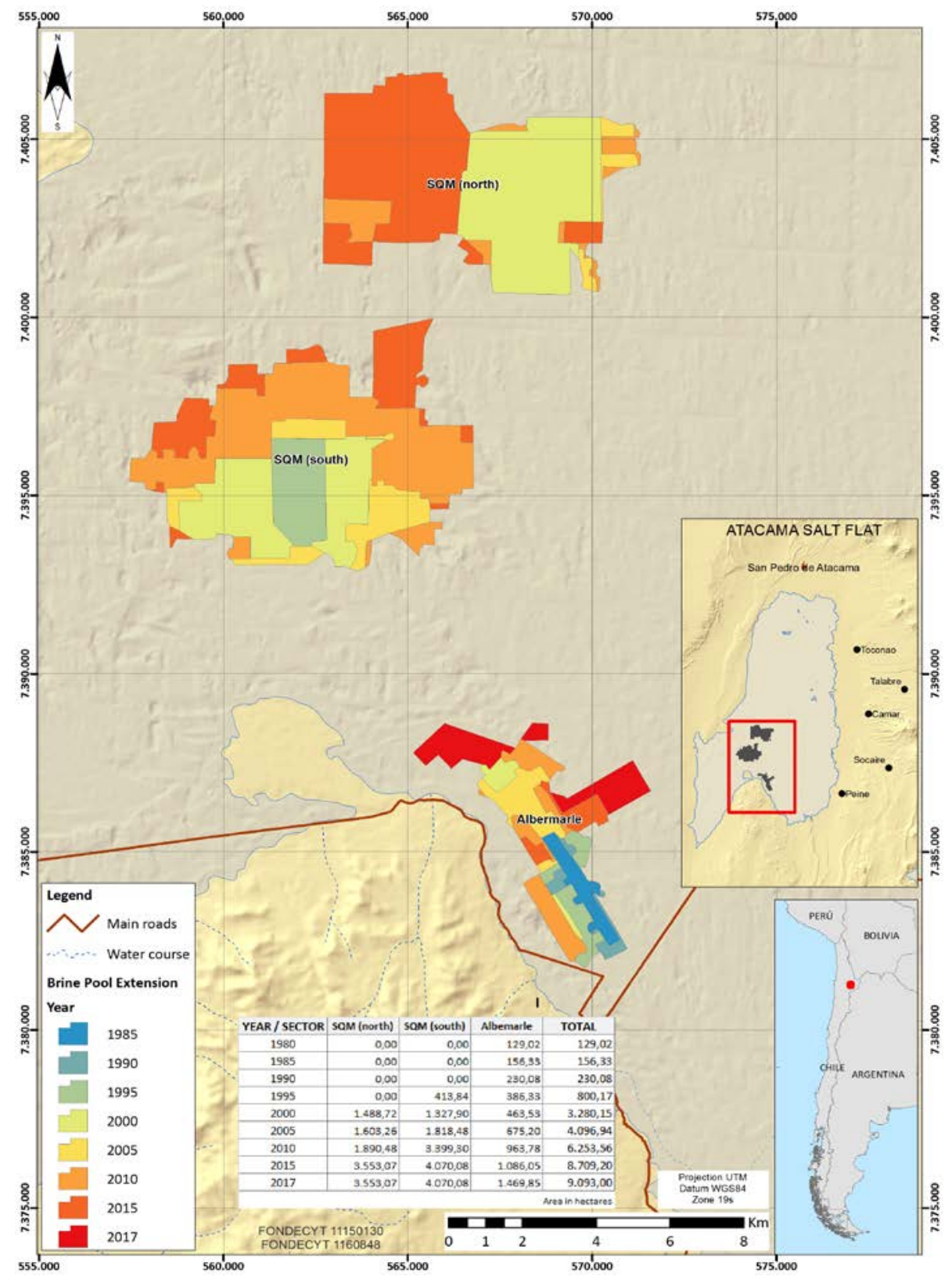

Figure 2: Brine ponds expansion.

\footnotetext{
${ }^{3}$ The Corporación de Fomento de la Producción de Chile (Production Development Corporation, hereafter CORFO) is a governmental organization created in 1939 to stimulate economic growth and development.
} 


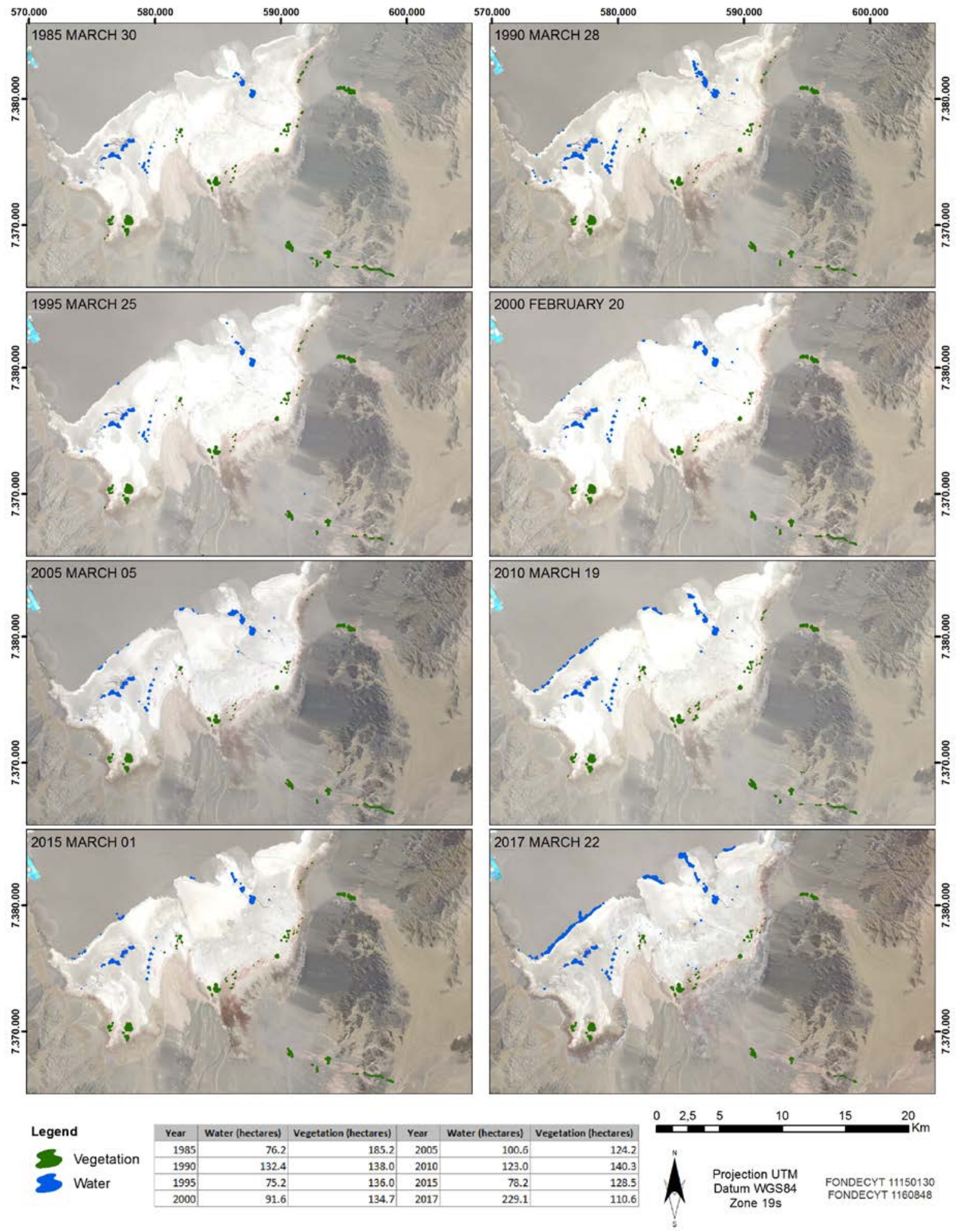

Figure 3: Land cover change. 


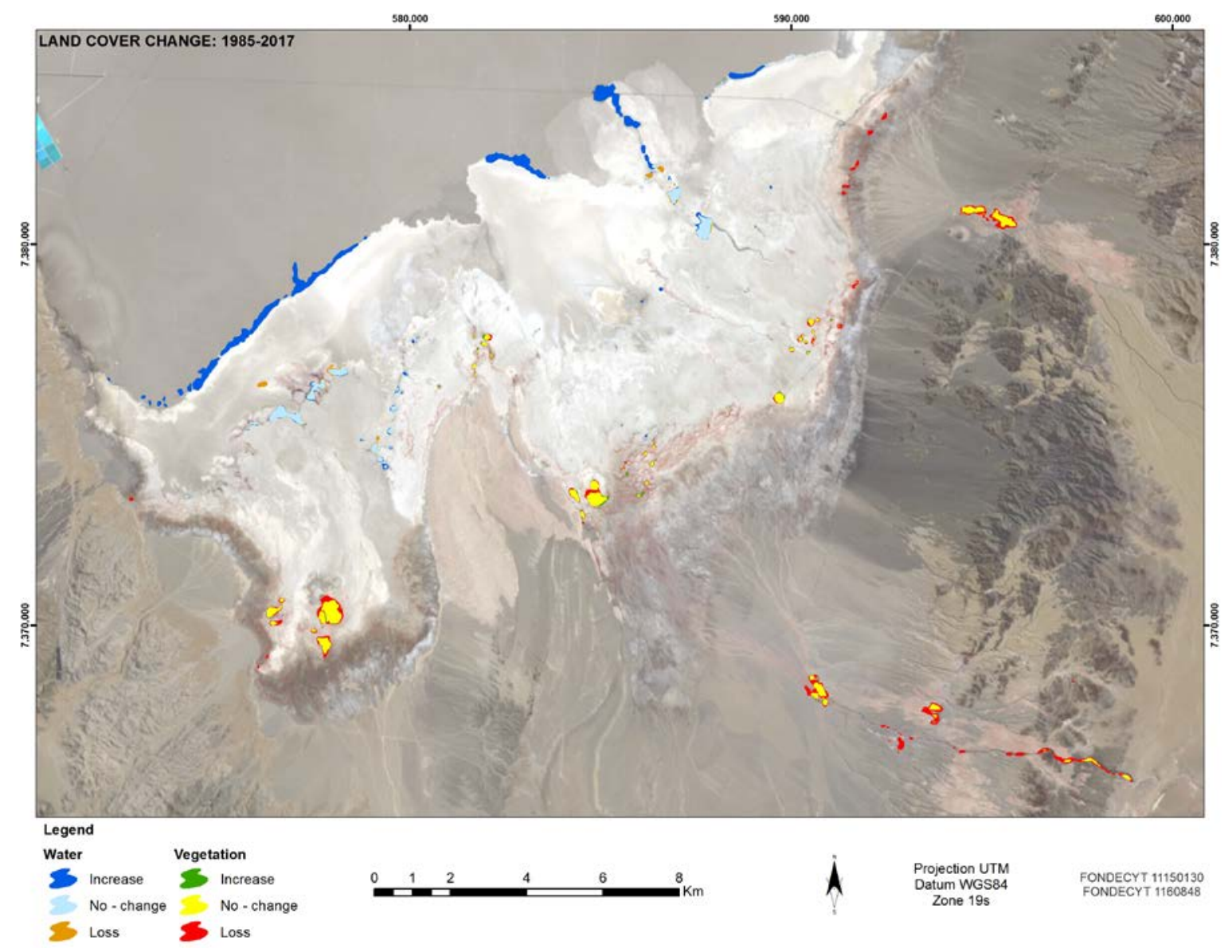

Figure 4: Land cover change, detail.

The bulk of the water rights in the Salar de Atacama basin belong to MEL (1,400 liters per second, 1/s), and its neighbor CMZ (556.5 l/s). While water extraction rights are granted in perpetuity, the DGA's recent declaration of 'prohibition' on the southern Salar (discussed below) has meant that both companies must renew their environmental license, which includes quantities of water extraction (in 2019 and 2021, respectively). MEL is seeking to continue extracting water from the region, but at a lesser rate $(640 \mathrm{l} / \mathrm{s})$. CMZ, on the other hand, is allowed to extract a maximum of $38 \%$ of the total of its water rights $(212.75 \mathrm{l} / \mathrm{s})$; currently, the company wants to maintain its current extraction rate from mid-2025 until 2029. ${ }^{4}$ The requests of both companies are in tension, generating a conflict between them.

Operating on the Salar itself, the two lithium companies also have rights to extract freshwater and there are three other extractive corporations with interests in the Salar, though none yet with environmental approval to begin extraction (they include NX Uno de Peine, Wealth Minerals and Lithium Chile). Lithium production demands the extraction and evaporation of high volumes of water for obtaining the final products (potassium, lithium carbonate, lithium hydroxide). It requires pumping large volumes of brine (water with a highconcentration solution of salt) located under the salt crust of the Salar. After the brine is drawn out, it is poured into ponds situated in the salt flat's surface (see Figure 2). Here the brine is exposed to the Atacama Desert's sun and as a result the ponds accumulate potassium, which is harvested in early stages of the process. When the

${ }^{4}$ Figures and detail taken from Environmental Impact Assessment reports by MEL, 'Proyecto Monturaqui' and CMZ 'Continuidad Operacional Compañíia Minera Zaldívar', Environmental Assessment Service (Servicio de Evaluación Ambiental, sea.gob.cl, last accessed 28/5/2019). 
brine in the evaporation ponds reaches an optimum concentration of lithium, it is removed and transported to industrial plants near Antofagasta, where lithium carbonate and lithium hydroxide are produced. The whole process takes approximately between 12 to 14 months.

According to SQM, a small amount of processed water and mineral (as 'brine') is recovered after processing which is reinjected into the salt flat. ${ }^{5}$ The process demands large quantities of freshwater for keeping the industrial process lubricated. According to official records, SQM has the right to extract $240 \mathrm{l} / \mathrm{s}$ of freshwater and Albemarle has the right to $24 \mathrm{l} / \mathrm{s}$ (DGA 2012). While significant, these quantities are lower than the volumes of water extracted by copper miners. However, when considering the water contained in the brine, SQM is authorized to extract 1,700 l/s and Albemarle $442 \mathrm{l} / \mathrm{s}$ (Jerez Henriquez 2018: 28). Due to the fact that saltwater is not regarded as "water" under the Chilean Water Code (1981), lithium companies do not require water rights for brine extraction, making their water extraction (of brines) invisible in terms of whole of basin water management and environmental regulation in the Salar de Atacama.

Current reports by the DGA declare that the 'hydrological balance' of the Salar indicates that more freshwater is extracted than can be naturally replenished. That is, that the DGA's recent hydrological modeling finds that the amount of water naturally occurring and being replenished by inward flows to the basin (minus evaporation and evapotranspiration) is less than the quantities that have been granted to and used by extraction interests (including but not only those mentioned above for the southern Salar). The DGA has previously declared water basins fed by surface water in the Antofagasta region exhausted (literally with a 'Declaration of Exhaustion' [agotamiento]), most notably the Loa River basin to the immediate north of the Salar de Atacama. ${ }^{6}$ Pertinent to our case, the DGA's 2014 study of the Salar (see DGA 2014) concludes that in the Tilopozo sector water rights granted combined to a total amount of 2,427 liters per second, with only 403 liters per second of natural inflow. Using such modelling, we might say that this area of the salt flat is over-exploited by six times the water recharge capacity. In 2015, the DGA declared a restriction in granting further rights to extract and use these waters (Resolution $\mathrm{N}^{\mathrm{o}} 120$ ). However, in other areas of the Salar's basin, the DGA has continued to grant more water rights to extractive industry actors without taking into account the water balance of the whole basin. This situation threatens to produce impacts on the groundwater reserves as well as on the protected wetlands. Finally, new technical reports conducted in 2017, have led the DGA to declare a "prohibition" on the extraction of water in the Tilopozo area (Resolution N 13, June 22, 2017). A definition of prohibition means that "the availability of the resource is completely compromised in definitive and provisional terms" and that it is not possible to create new rights to water in this area (DGA 2017).

Thus there is a long history of extractive activities in the southern Salar, beginning in the 1970s on a small scale but reaching the above rates of extraction by the late 1990s (see Figure 2 and Comisión Chilena del Cobre [COCHILCO] 2017). Recent declarations and actions of the DGA indicate significant regulatory concern for the ecological health of the Salar. However, we note that these responses do not and are unlikely to prevent the accumulating ecological threats at least partly because the Water Code (1981) grants private and perpetual water rights that cannot be revoked by the state except by special expropriation law and extraordinary conditions. The DGA's declaration of prohibition in the southern Salar does not change the fact of ongoing and already conceded rights to extract water throughout the basin that far exceed what the environmental conditions may sustain. Significantly, nor does this declaration of prohibition protect against the potential impacts from the lithium industry, since the environmental modelling discussed above does not include the quantities of salt water that industry extracts. Thus the DGA's declaration of prohibition comes too late and is too narrow, since while it appears to prevent further extraction, it recognizes the problem only once exhaustion has occurred, in a specific area of the basin, and only prohibits future grants to extract freshwater.

The recent extractive landscape of the Salar includes an exponential growth of the lithium industry (with additional interests seeking to enter the field), thus any meaningful consideration of hydrological modeling would also need to account for salt water (brine) extraction. According to environmental impact regulations, each company operating in the area must demonstrate the ways in which their extractive activities affect the specific zone in which they operate. As a representative of the DGA noted during a commission of inquiry in

\footnotetext{
${ }^{5}$ See report Cámera de Diputados (2016).

${ }^{6}$ See online DGA map of restrictions on the extraction of water.
} 
2017, the government does not have a whole of basin model of water availability, which is a complicating factor in the regulatory analysis of the environmental models produced by each extractor (Cámara de Diputados 2017: $88,96)$. A problem as a result is that each of the models of impact produced by extractors only consider their own, or perhaps one other extractor's rates of water extraction. As models of impact, each may thus assert 'sustainability.' 7

The Peine Indigenous Community has ongoing territorial, sociocultural, and ecological interests in the southern Salar and leaders of this community and others have recently made public comments that express their concerns about mounting exhaustion both of people and the environment as a result of extraction industries. For example, the President of the Community recently stated:

It seems irresponsible on the part of the government, of the authorities, to keep installing mining projects in an aquifer, in a basin, which, in reality, no-one knows whether the recharge that it has is more or is the same as the extraction that is occurring. As I said, hard data, almost 4,000 liters is leaving the aquifers. And today, with all we know about climate change, about how the rains happen in the north of the country, in reality I am compelled to say that it would not be enough to recharge even the half of that water to the Salar de Atacama. Above everything is the social impact of this. This also generates divisions in the social fabric of the communities. (Comisión Investigadora Acuerdo Corfo SQM 2018, 25:08 - 25:55 mins)

Our discussion of the ways in which an ecology (the Salar) and its exhaustion is known and understood combines the accounts of indigenous people's knowledge of their territory and their experience of the 30+ year history of mining industry extraction. In the southern Salar, people's experiences of the history of mining and extractive activity shape the ways in which they see and respond to the threat of ecological exhaustion from the industry's extraction of fresh and salty water. The data we discuss in this article reveal how local knowledge not only provides a complementary explanation to scientific data regarding socio-environmental phenomena, but also highlight the need to undertake collaborative and participatory based scientific studies. Our discussion takes up the epistemological and political tensions between scientific and local or indigenous knowledge to consider the ways in which territorial transformation from extraction is experienced. We discuss below the ways in which people in Peine narrate the steady growth of the extractive industry and associated social and environmental effects. Alongside the picture of exhaustion is the finding that the Salar, as a cultural, natural, historical, and industrial landscape, has had the capacity to generate new ecological experiences and memories for Atacameño people.

\section{3. 'Desde siempre': the deeply known place of Tilopozo}

People from Peine recall the Salar as a place that has always ("desde siempre") been in use, or people say they have always been there ("siempre han estado alli"). Such expressions of relational knowledge are common to the ways in which indigenous peoples articulate autochthony. They are also forms of deep time memory, where people experience and remember experiencing themselves is entangled with what their parents or grandparents told them of seeing; it is the sum of what they heard from the past and what they have lived.

In Tilopozo, people's contemporary uses of the place (within the last century or so) are evidenced by the presence of estancias (or farming and ranch steads) made from the Salar's salt crust and historical cultural materials such as horseshoes and glass (L. Núñez et al. 2008). These material clues to the past have also been recorded in ethnographic work conducted in Peine regarding use of territory and claims to territorial rights (see for example, Dransart 2002; Kalazich 2013, 2015; M. Núñez 2000, 2015). Local people's living memories of Tilopozo reach into the 1930-1940s, from some of the current elders' childhoods, although the majority recounted experiences of the place centering on the decade of 1970-1980, the last period during which Tilopozo was regularly used for herding of sheep and llamas.

\footnotetext{
${ }^{7}$ MEL, CMZ and Rockwood (now Albermarle) have held periodic collaborative discussions about extractive impacts on the southern Salar in the past, and MEL and CMZ trade water modelling and environmental impact studies (see Camera de Diputados 2017).
} 
In the pre-1970s era, when people from Peine recall the fields and broader landscape being green, with more fodder and water for the animals, and when herding was one of their main economic activities, each family might have up to 200-300 animals (sheep, llamas and goats) (Kalazich 2013: 173-174). The cold season herding took place in two areas: one within the grazing fields immediately east of the town and on the path to the Tulan canyon, located some $14 \mathrm{~km}$ south (at altitudes of 2,600-3,000 masl). The other area, at the salt pan level, articulated the oasis of Tilomonte, the vega of Tilopozo and the estancias of Tilocalar (2,300-2,500 masl) (see Figure 1). Thus, for the herders of Peine, places such as Tilomonte were permanent settlements during the autumn and winter months. The oasis of Tilomonte was in permanent, year-long use. Few families lived there throughout the year, since children from ages 5 to 11 attended school in Peine (and the elder children went to school in Toconao), thus it was mainly childless couples or one member of a family who would stay in this oasis. As an agricultural oasis (cultivating mainly maize and alfalfa) there was little grazing for animals and in this sense Tilopozo and Tilocalar were the locations for herding at the south of the Salar, with people traveling back and forth between Tilomonte and Peine (Kalazich 2013).

Most of the vegas that Peineños used for herding are located in the higher adjacent Andean mountain zones, such as Cabus and Pular. However, these vegas are not accessible during winter and autumn months. This important regional difference between Puna Seca (Arica to Lirima) and Puna Salada (Lirima to Copiapó River) is that while the former is inhabitable all year long, the latter has extreme weather conditions which do not allow the continuous use of this space except throughout spring and summer months (September to February) (Núñez and Santoro 1988; Troll 1958). Therefore, during the cold season (March to August) the inhabitable spaces correspond to the Salar level (2,100-2,600 masl) and the inclined plane with its numerous ravines (2,600-3,850 masl). Thus, Tilopozo (2,320 masl) is one of the few vegas within the latter altitudinal floors that can be accessed during the cold months (see Figure 1).

Three to four families (mostly couples) with their herds would make use of the Tilopozo vega at one time, taking food supplies for at least a week. Other family members would visit occasionally, especially during the weekends, bringing more supplies. People staying in Tilopozo also hunted small mammals and ate tubers from plants that grow naturally in the place and made use of the pozo which those who were children at the time remember with pleasure. In their journeys to Tilomonte they would bring other supplies, as well as news from Peine and people herding elsewhere in Peine's territory.

Women herders staying at Tilopozo recount stories from the late 1960s, when men undertaking exploration for CORFO were coming and going and sometimes stopping to speak with them or give them canned fruit and treats for the children. From the early 1970s, CORFO employed local men from Peine to assist in the exploration process in the Salar. They helped make the roads, the first of which was a road to Tilopozo now marked by a milestone near the edge of the Salar as "zero kilometers". Peineño men were hired as guides, since they knew the Salar and how to "walk well" across its surface (a man about 70 years old interviewed, 2013). CORFO also hired men from Peine to drill survey bore holes for minerals and excavate some test evaporation ponds in different areas of the southern Salar near Tilopozo. CORFO also built a dormitory and residential area on the eastern edge of the Peine community on terrain excised from community land by a government body (Bienes Nacionales) that is still used. As noted above, the first brine extraction operation on the Salar (now owned by Albermarle) employed many local men. Local women and men started small businesses, enabled by increased cash flow and the custom of external workers.

Peineños recount that around the early 1970s the "green fields" full of pasture for the animals decreased significantly, which implied a drastic beginning of the end of pastoralism as a main economic activity. After the 1970s and until the 2000s, two couples from Peine continued long-distance herding, making use of Tilopozo, Tilocalar and the Tulan canyon during all seasons and despite growing industrialization of the territory. Since the numbers of grazing animals was dramatically reduced, it was not necessary to go all the way up to the Pular and other highland vegas whilst the grazing fields recovered for the next cold season. The higher Andes were filled with anti-personnel mines in 1978, given Chile's frontier conflict with Argentina, making the journey to the mountains dangerous and contributing to the end of highland herding amongst Peineños. Most of the herders retreated to Peine, keeping a reduced flock (5 to 20 animals), which are fed mostly with alfalfa and maize husks from their own or locally traded garden produce. At this time, too, military detachments stationed in the southern 
Salar stole Peineños' crops from Tilomonte, motivating the discontinuation of subsistence agriculture in that oasis, whilst encouraging people's search for work opportunities in the mining industry (Kalazich 2013, 2015).

Archaeological material from Tilopozo - mainly projectile points and pottery fragments - supports occupation during the mid-Holocene/mid Archaic (ca. 6,000 BP) Early Formative (ca. 2,800 BP) and PostHispanic Periods (1,550 BP - present) (Núñez et al. 2008). Tilopozo was an important water/fodder place for people using the ancient roads that became part of the Inca trail (Qhapaq Ñan) during the Late Period (1,450 1,530 BP), when several Inca structures (tambos, saywas) were added, although not in Tilopozo itself (see Niemeyer and Rivera 1983; Sanhueza 2005). Several travelers, naturalists and/or government officials visiting the Atacama Desert in the late 1800s and early 1900s (e,g. Espinoza 1897; Magallanes 1912; Muñoz 1897; Philippi 1860; von Tschudi 1869), describe and/or highlight Tilopozo as a place with water (although mentioning neither quality nor relative scarcity), with corrals for animals and "alojamientos" (dwellings) for people. These authors all emphasize Tilopozo's place as a rest stop along the route that connected the towns of the Salar with herding and mining places close to Llullaillaco and populated areas farther south such as Copiapó. In such documents of Tilopozo's environmental history, it is a watered place on a long stretch of arid landscape. As we outline above, for the people of Peine, Tilopozo has "since always" been much more than simply a stop along the road.

In recent years, the pressure from mining companies already exploiting water from the southern Salar region or seeking to exploit it in the future, has been an important stimulation for the use of territory by Peineños, to which more recent rainfall and therefore grazing pastures has also contributed. In February 2017, a group of Peineños (elders, adults and children) walked with their sheep to Tilomonte along the ancient trails, reliving the transhumance and passing down herding practice to the younger generations. In the account of an older woman and one of these herders:

They told us one time that... the Tilopozo waters that we always used before, as vega pastures and everything, [that] the companies were going to come and take the water, po'. ${ }^{8}$...So we were concerned that suddenly the vegas were going to dry out, there would be no pasture for the animals. Because, when I was a girl, there were many animals. Mules, donkeys, and people moved with their herds. Many took their animals to that pasture. So I was brought up seeing those things and would go there, taking the animals to pasture with my mother and my father. So I always remember this... Anyway, we said, [my daughter] said to me one time, "mami, why don't you take the sheep to the pasture there?" "I don't know, then"', I said, "there are so few sheep". But even so, for one to relax, to spend some time there, we could go. So we decided to go. "Yes" I told her, and we had agreed.

There was a meeting in the Community about this. About the vegas, about the water, everything. They proposed, "why don't some of us who have sheep go and stay there for a week, or if we want, more? And people can come and help us cut feed [for the animals]". ... And so we decided to go, and we went. We advised the people in charge of the Community and told them we were going. After, they said that [another señor] was going to go. He went to Tilocalar. He didn't go to Tilopozo. We went to Tilopozo. (Interview, November 2017)

The southern Salar, including Tilopozo and Tilocalar, is vital to Peineños' herding past as well as a source of contemporary cultural identity and relationships with territory. Many regard this legacy as a constitutive element of who they are today and have been for more than a millennium: herders. Aside from the paramount importance of Tilopozo as a water source for Peine within the desert's aridity, it is a place of memories and memory-building when visited; it is both tangible and intangible cultural heritage of Peine. In this story about returning to Tilopozo, a woman with a long history of pasturing animals recounts the ways in which she and others sought to spend time in the place as part of a response to their fears of the place drying out, being exhausted, from water extraction. For this woman, a desire to be there includes the attraction of

8 'Po' is a Chilean colloquial utterance derived from the Spanish word 'pues' (then). We leave it in the transcription where it retains the emphasis in the story being told. 
'relaxing' in a place, a contemporary expression of the value of Tilopozo as a place of recreation particularly comforting since it is associated with deeply-held memories and ownership. As we discuss below, memories may be stirred by collective reflection about a place (as in participating in the mapping workshop), but such reflection may also produce new or renewed configurations of memory in the face of threats from extraction.

\section{Mapping environmental change}

In a context of ongoing growth of extraction industry activities in the southern Salar (the growth of existing brine extraction, potential renewal of water extraction licenses by MEL and CMZ, and additional interests), the authors were approached by the Peine Indigenous Community to assist with independent reporting on environmental and social impact. As part of our response, we proposed undertaking a participatory mapping exercise with Community members. The process involved the creation of a set of 'land cover maps' to examine surface change in water and vegetation and expansion of brine ponds by both lithium companies. The landcover maps were produced using supervised classification of Landsat TM and Landsat 8 archives. We analyzed a sequence of eight images of the study area (1985, 1990, 1995, 2000, 2005, 2010, 2015, and 2017) (see Figures 2 and 3). ${ }^{9}$ We elaborated tables with climatic data, which allows the consideration of precipitation data in relation to landcover (Figures 5 and 6) ${ }^{10}$ We emphasize the point made above; the maps were not produced to give a definitive quantification of change, but to show landcover variability as detected in the images on an interannual basis. Additionally, the maps were designed to serve as a prompt and visual reference for discussion of landscape change, on the basis of which locals could interpret, concur, disagree, or frame their own perspectives in relation to what is represented in the maps.

In November 2017, the authors undertook a participatory workshop in Peine. The maps were a material focus for eliciting discussion of environment and social change in the southern Salar. We note that elected leaders of the Indigenous Community (organization) made a special effort to ensure two members of the seniors group (adulto mayor), a woman (about 65 years old) and man (about 80 years old), attended. Both seniors were involved in pastoral activities in the vicinity of Peine and in Peine's broader territory up to the early 1980s, and sporadically since that time. They have also been key actors in growing their herds and reviving pastoral practices with the return of higher rainfall and pasture in the past 3-4 years. In addition, the senior man has been in charge of the weather station in Peine since the 1970s and has technical skills that reflect this and other work he has done stretching from working with CORFO in the late 1960s to the early operation of the (now Albermarle) brine mine and other industrial and technical work. Other participants in the workshop were in their 20s, 30s and 40s, with a mix of genders. Our results represent information from a small group (n=12), but one that spans the adult age groups and includes participants that community members consider some of the most knowledgeable about the Salar (i.e. 'organic intellectuals' of the Community).

During the exercise, we facilitated discussion around three main sets of questions with the dozen participants. First, they were asked to consider a timeline of "events in their lives that mattered." Given the age range of participants (ca.20 - ca.80 years old), we may take the potential temporal period of the results reported below as early 1950s to the present, although most participants focused on changes from the late 1970s onwards. Second, and using the satellite images and maps as visual aids, participants were asked to reflect on changes in the environment, and third, to articulate the connections between specific impacts and broad changes to their

\footnotetext{
${ }^{9}$ To prepare the change maps, we delineated training fields representative of the range of spectral characteristics displayed by its corresponding land cover classes (i.e. vegetation and water). The training fields guided the classification of each image, using the classification module of QGIS 2.16.3 software. Once the images were classified, we performed a multitemporal analysis for the estimate of the land cover change in major classes between 1985 and 2017 and calculated the area of change between years (see Figure 4. As a base image, we used a false-color Landsat Image (bands 5-4-3) from 3/22/2017. Figure 2 was produced using the same Landsat images. We applied a photointerpretation process for identifying the area of the brine ponds per year. The area is mapped in three sectors of ponds: Albemarle lithium producer, SQM lithium producer's northern, and SQM lithium producer's center. These polygons were colored according to the year analyzed. Finally, we calculate the area of each polygon in hectares per year and the grand total.

10 The tables with the climatic data were elaborated using the data available in the CR2's Climatic Explorer (http://explorador.cr2.cl). The data represented the hydrological year (November through May) corresponding to each year of image analysis.
} 
lives as associated with the beginning of the mining industry (ca.1980 to present) and depictions of change on the maps.

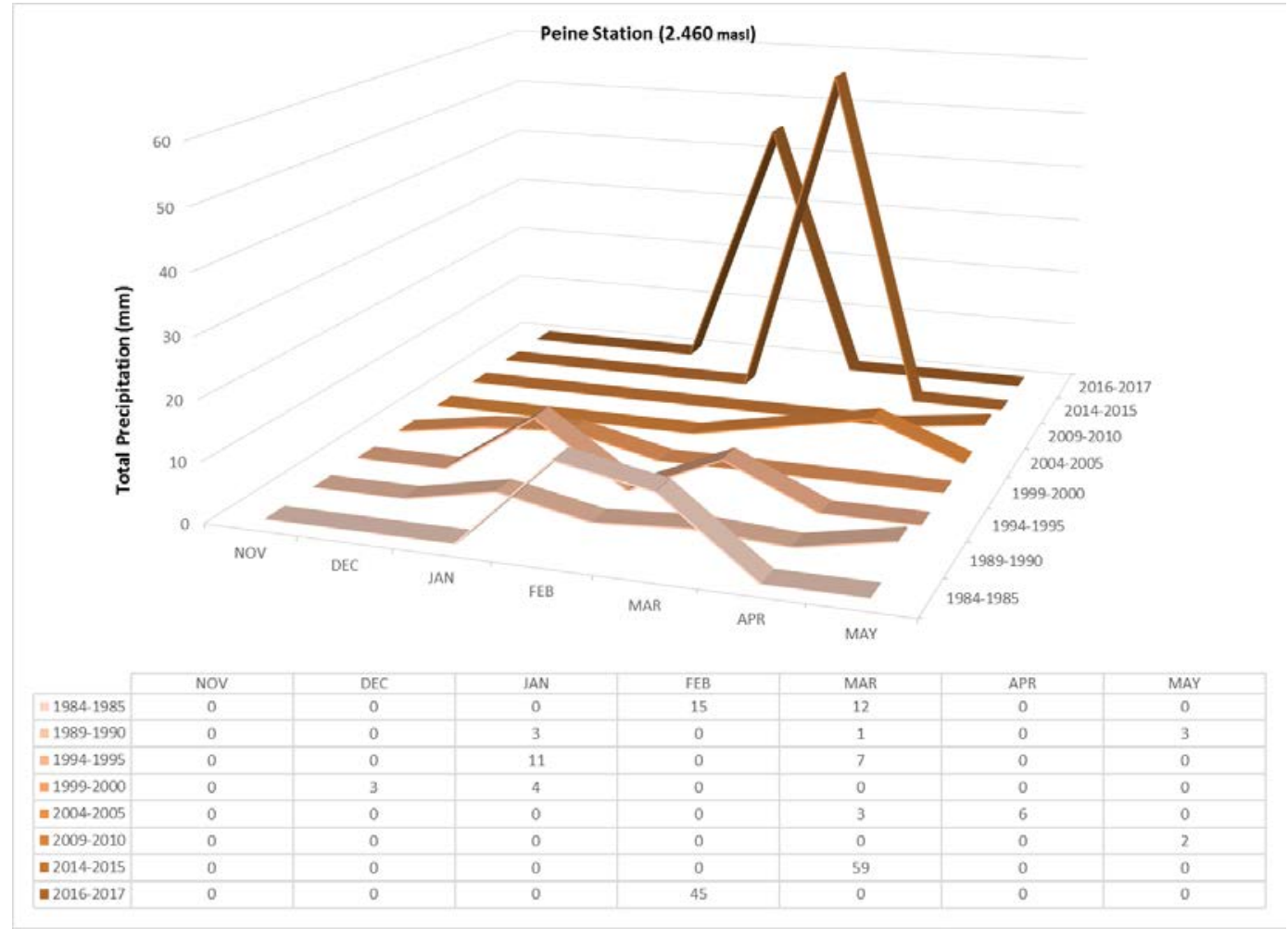

Figure 5: Total precipitation, 1984-2017 (Peine station).

\section{Talking about change}

The research that we report here focuses on participant answers to questions we asked during the workshop about "environmental and other change to life in the southern Salar." People took the term "environment" to designate their surroundings in an expanded sense (including the town of Peine itself as well as the whole southern Salar, especially those areas represented in the maps we produced) and a broad range of changes (negative, positive and ambivalent) to life and the surrounding territory. As mentioned above, the end of long-distance transhumant pastoralism, catalyzed in environmental terms by the disappearance of pasture as a consequence of the long drought (roughly beginning in the early 1970s) marks a key reference point for people's sense of change. As a 'conjuncture' (Murray Li 2014), we know that around the same time industrial activity began to appear on the Salar (as CORFO began exploration), this inspired various economic responses from locals as well as global and national interest in a region that had previously been largely invisible to the state. Below we summarize people's responses to our questions of change, while highlighting aspects of what they said in regard to continuities (desde siempre) that reflect a reality that was the same for a long time. In a sense, the beginning of industrial extraction on the southern Salar is a memorial breach in time and memory, since before the 1970s, implies a time "before environmental change." 


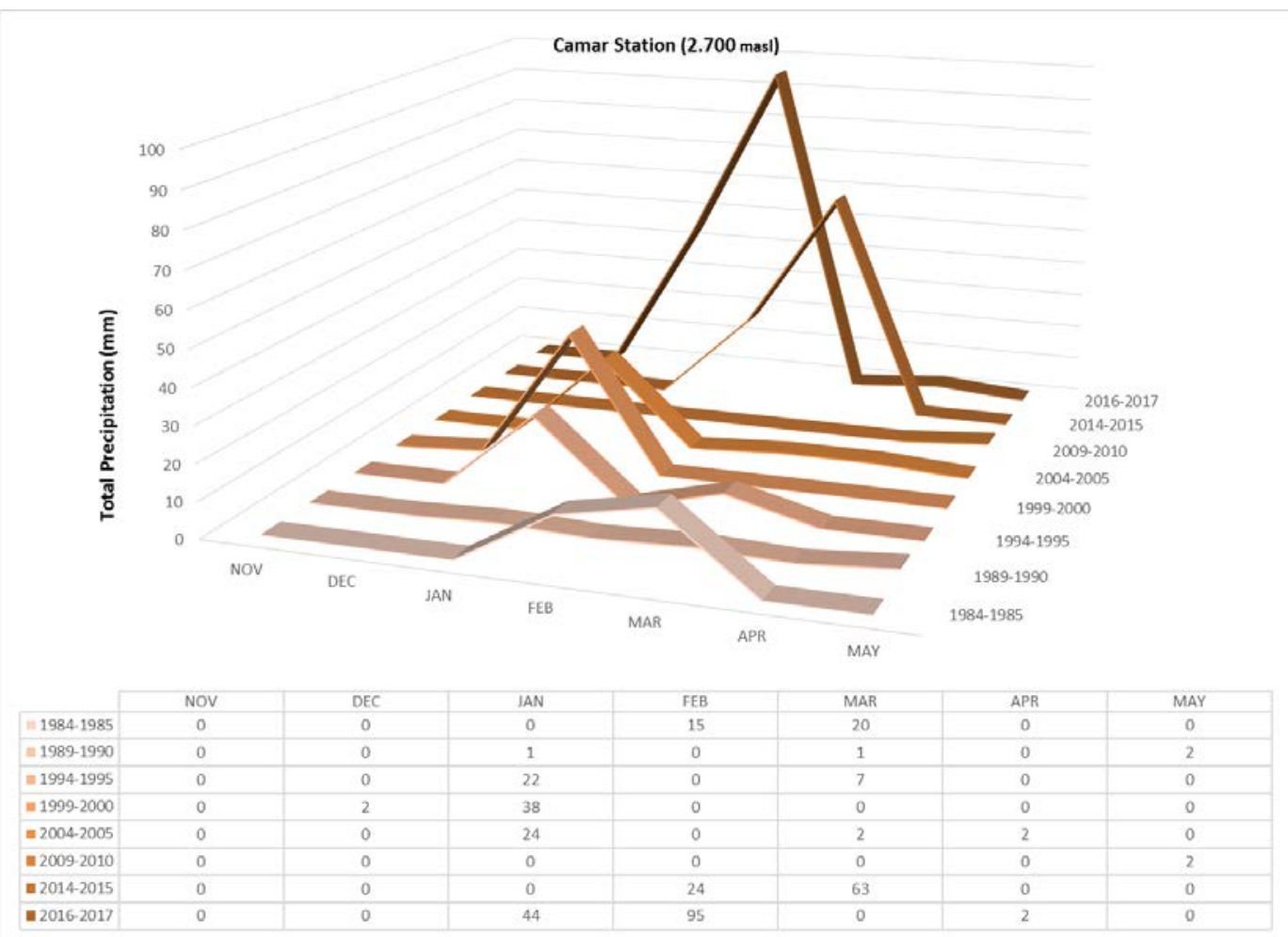

Figure 6: Total precipitation, Camar station, 1984-2017.

Every year, the population of Peine grows. The senior woman participant (ca.65) noted that "it used to be really calm (tranquilo) here, not anymore. It [change] was severe (fuerte)." Construction of dwellings has expanded outside the old boundaries of the pueblo, with this seen as "territorial expansion to satisfy the necessity for accommodation" (woman ca.30). One participant linked the need for accommodation to the fact that with "the mining [industry] so the number of contracting companies has grown."

While subsistence agriculture continues to be an important part of life for almost every family in the community, and most still have at least a small herd of animals, there is less time and dedication to these than in the past. During the workshop, a woman (ca.35) and an older agriculturalist (ca.65) discussed their experience of the drop in numbers of amphibians, the appearance of insect plagues and increase in weeds that have appeared in agricultural crops, where there was little recollection of such things before. People from Peine continue planting, field cultivation and harvesting in the same well-defined sectors as always used in Tilomonte ${ }^{11}$ and Peine, although some families no longer are involved.

Up until the mid to late 1970s, people from Peine would harvest parina (or flamingo, Phoenicoparrus andinus, Phoenicoparrus jamesi and Phoenicopterus chilensis) eggs and a range of ceremonial practices were associated with the harvest. Participants recounted that around the 8th December:

\footnotetext{
${ }^{11}$ During the Chilean dictatorship (1973-1990) military personnel stationed in Imilac stole crops and trampled fields in Tilomonte, causing some to cease planting there "Nadie sabe pa' quien trabaja" (no-one knows for whom they are working) said one don señor, about the military stealing crops. Agriculture in Tilomonte picked up again after the end of the dictatorship.
} 
[woman ca.65]: ... a day before there would be a notice, there would be a person advising everyone that on this day they were going to get the eggs. The people got themselves prepared with their animals, taking little boxes and all that....

[woman, ca.35]: And would you take them all or leave some?

[man, ca.80]: no [not] all. What was there we would take. We would say 'all the eggs are taken' and from then no-one else would enter. Afterward, they'd go in February when there were chicks and they'd stay there. They'd go along the river, towards the headwater, and you can still see, you could see there was a little corral there which accommodated them.

[woman, ca.35]: what would they do there?

[woman 2, ca.35]: they would decorate them, put earrings on them.

[man, ca.80]: They would release them towards the river, and they would go. They knew what quantity had remained.

[woman 2, ca.35]: Close by there, following the river, at the end, on the left. There is still a little wall. There are the remains of a bottle that they used to do the convidos. ${ }^{12}$

The collection of parina eggs was a process closely managed by the community, with expectations regarding the timing of collection, the restriction of consumption, and practices that made sure that a great number of chicks hatched. The ritual accompaniment to the egg harvest is a notable aspect of the activity, with the remains of a built shelter and material evidence of oblation practices (see also Cartajena et al. 2010). The collection of parina eggs was gradually prohibited after the Convention on International Trade in Endangered Species of Wild Fauna and Flora (CITES 1973) and the Convention on Migratory Species (CMS 1979) were adopted as national legal decrees in 1975 and 1981, respectively. Further, the creation of CONAF in 1972 and its status as a national service since 1984 reinforced the protection of endangered/vulnerable species, without considering traditional indigenous practices of use and conservation.

Participants in the workshop emphasized that a significant change to life in the recent past was the town's provision of a new source of freshwater (agua dulce) in 1997 (Registered rights to Chaquisoke with DGA at $2.3 \mathrm{l} / \mathrm{s}$ ). However, as the population grows, there is "less water" available from this source. A concern recorded on an index card by a male participant of the workshop noted the steadily growing population in Peine, particularly from increasing numbers of mining industry workers associated service provision, and the challenge of needing more potable water. Another man wrote that the "danger of contamination in the water" is now prevalent, whereas "before there was no such fear for humans or animals".

Participants spoke about their experience of a few extreme weather events that punctuated their environmental history. For example, heavy rain and flows of water from the mountains in 2005-2006 resulted in flooding in Tilomonte (ca.15 km south of Peine) the flood waters destroyed one section of the fields and irrigation canals (La Banda sector). The community undertook communal work (trabajo comunitario) to fix the canals and fields.

The drying up of the wider environment due to drought was a focus of the group conversations. There is a "diminished amount of green areas" and one example of the "extinction of places where there was vegetation" was a small pasture within a couple of hours' walk [east-northeast] of Peine, called "Turi" which, before the 1970s had enough pasture for large flocks to be fed for a short period. Adding to this, the senior man in the workshop described the way springs in the broader territory that had been used previously for pasturing animals were no longer viable. He told the group, "the change most noticeable is the drying up of the springs (vertientes). Before, I knew the vertientes with water. Today, you find the vertientes dry." In the broader pastoral landscape, "there is less rica-rica [Acantholippia deserticola (phil.)], I remember that before there was more

\footnotetext{
${ }^{12}$ Convidos (convidar: invite, offer, share) are a widespread ritual observance in the Andean region. They denote payments to mother earth (Pachamama), to water, to the sacred mountains, among other non-human entities. Generally libations are with an alcoholic beverage, coca leaves, tobacco, and flour. Convidos are performed in ritual contexts (i.e., during a canal cleaning ceremony). How the convidos are performed depends on the community where they are performed and on their specific context.
} 
rica-rica on the road to Tilomonte. There was té de burro [Dinemagonum ericoides] and those things, they grew closer to the pueblo" (woman 2 ca.35).

Landcover maps (Figure 3 and 4) indicate that there is an increase in surface water in particular areas of the southern Salar, and that the lakes (Lagunas Salada and Saladita, Laguna La Punta, La Brava) have also experienced some change. Toward the end of the workshop, facilitators explained what the different colors on the maps represented from the satellite perspective. In the case of the lakes, the maps show some loss of surface water, but in other areas there is also more surface water after 2010. In response to the description of what the colors on the map indicate, a woman (ca.40) asked "But why here do we have more water and over there less vegetation?" The ensuing conversation saw various workshop participants, sometimes prompted by researchers, thinking through how the place and its changes might be understood.

[MP] Why do you think there is more water [in this area]?

[Woman 2, ca.35, indicating parts of the map]: Because it collected. All of this before, you would not see water there, the water was over here. And because it began to collect - the limits are here and the vegetation cover that is getting dry is here, here it's now all dry. The water is over here now, in this part.

[Man ca.80]: The lakes, that part when we were making the road through here, here the water passed over to there, by the road that goes out to el litio [referring to the brine ponds]. Afterward it dried up, it dried up the lake was dry and moved to the other side. It moves, this moves.

[Man ca.35]: What do you mean it moves?

[Man ca.80]: The lake and river moves. Because, because... CORFO, no, after... They placed a stake in the river, the river sunk. Afterward the river was on the other side and this side was dry. That's why I say it changes. After, when there was no water on this side, we went to see what happened and the lake was on the other side, not where they made the road. And now again, it is on the other side and the other side is dry. That is the problem with that lake, it changes sides.

[SB]: So it just changes, naturally?

[Man ca.80]: Naturally. Just like Salada and Saladita, we used to call it Laguna Redonda [Round Lake], it was a little circular [redondita], now it is long, not round.

[MP]: So why is there water there [indicating maps] now, in these last 17 years, and between '85 and 2000 there wasn't water?

[Man ca.80]: That I don't know. Because here what you see [indicating map] is that the lakes are right there. Like I say, this is the only part that changes from one side to the other, it is the same river. But from there I don't know. It was there when we entered the Salar, in the part of the Salar there was a river, it only had a little water, very little water.

[FK]: ...But, don [señor], was [the change] seasonal or from one day to the next?

[Man ca.80]: No, from one time to the next. It's been many years! I don't know, I can't explain why it changed.

[FK]: Sure, so it just changes, like that?

[Man ca.80]: Sure, yes. Like I said, what they marked, where they marked the river, afterward the river was on the other side.

[Woman, ca.20]: And did it return to the other side after?

[Man ca.80]: no, it went to the other side, it didn't return.

The conversation illustrates a number of aspects of Peineños environmental knowledge of their hyperarid landscape, especially the minutiae of the features of surface water. People's livelihood depended (desde siempre) on walking across the Salar to reach pasture and access natural resources. It was for this reason that men from Peine were hired to help survey and make the road for CORFO. They have particular memories of features including streams or 'rivers' that feed the lakes, the appearance of wetter and drier areas of the surface 
of the Salar and the qualities of the lakes themselves. The senior man mentions that the lakes now named 'Salada' and 'Saladita' were in the past referred to as 'Laguna Redonda.' The contemporary lakes (plural) have not only had a name change but have become multiple and differently shaped. Awareness of these interesting changes to the surface of the Salar was prompted by speaking about and looking at the maps we produced, but there is no correlation between the memory of surface waters moving around and changing shape and the landcover change images.

Rather than a complete interruption to people's access to the Salar, the beginning of industrial extraction meant the imposition of new uses, boundaries, interpretations of the environment and names of landscape features. Men and women have continued to monitor the environment for its changes, with young people remembering features of the lakes from visits during their childhood and the senior man recounting features of the surface water witnessed during the period in which he and other men worked on building roads across the Salar in the beginning of the brine industry. The changes of this kind come with some uncertain questions about whether areas close to the industrial extraction points had resulted in a lake drying out. However, some ways in which people have seen the changes occur in the lakes and surface water may not be directly related to extraction. As noted, the change in the lakes from 'round' to 'long' and the witnessing of a 'river' and lake that 'changes sides' were discussed in the workshop without definitive indication of such changes on the maps themselves. Instead the reference point for the discussion is being in place at a particular period of life, where place is relative to ground level landmarks (el litio, the road), and the experience of change is relative to event. Such changes as experienced by Peineños in the environment indicate the 'unorthodox' nature of the Salar and thus raise important questions for future investigation.

\section{Extraction, unorthodoxies and exhaustion}

Our data show how environmental change is experienced as multifaceted and related to water in the taps as much as to changes in the waters of the Salar. Following DeSilvey (2016), our results also question the proposition that memory loss is inevitably associated with ecological exhaustion. The physical effects of extraction and ecological damage are outlined in the results of the research, but memories of this landscape have not been erased. In the 1970s a conjuncture of multiple factors of change including drought, decreased pastoral practice, industrial activity and extraction, wage labor, agricultural practice, new economic relations brought forward by free market capitalism, mining and privatization of water. These multiple changes have been systemically exhausting, causing different scales and kinds of social and environmental depletion. Nonetheless, people have responded to political, economic and industrial changes (since the 1970s) in productive ways. For example, in early exploration for minerals and mine construction, local men gained work that relied on their knowledge of the Salar, working in the mine itself and opening businesses that relied on, and thus continued experiential relationships with it. More recently, with water extraction for copper and brine reaching a point of exhaustion, some people have responded in ways that articulate deeply founded relationships of responsibility to the Salar associated with ongoing management and proprietary interest, for example, renewing herding practices. As the Community President noted in 2018, the social relates inextricably to the environmental and there are multiple effects of extraction. ${ }^{13}$

The changing and moving salt lakes, we argue, can be understood partly in terms of what Cruikshank $(2005,2012)$ refers to, in relation to First Nations peoples in northwestern Canada as the "unorthodox behavior" of their natural world. Local knowledge of the Salar may be seen to include the "tacit knowledge embodied in life experiences and reproduced in everyday behavior and speech" (2005: 9). While located in place, knowledge is not static (as in the "traditional knowledge" of TEK frameworks), but historically leaky, negotiated, responsive to events and with what Cruikshank calls "encounters" through time between humans and nature, as well as among humans. Conveying knowledge of environmental phenomena may not emphasize understanding but disjuncture and environmental things may be known for incommensurate behavior (2005: 10). Environments may be unorthodox in the sense that things appear and reappear without clear explanation,

\footnotetext{
${ }^{13}$ He was also apparently referring to conflict among Indigenous Community leaders and members that centers on debates about the ethics of and existing terms of relationships among Communities and between them and the extraction industry. This issue is beyond the scope of this paper.
} 
perhaps mobile instead of fixed in place. Likewise, the landscape or things within it may be known to respond actively to human proximity or behavior. Such ways of understanding the environment may be at odds with scientific knowledge and in some cases intersect with it. In the mapping workshop, the maps prompted a story about the ways that surface water has changed, but the environmental changes had no graphic corollary. This lacunae in independent scientific study of the environment of the Salar de Atacama means there is no competing explanatory framework for the 'lake that moves.' However, it may be less important to resolve this phenomenon than use it to emphasize the potential of these unknowns.

Researchers were recently at a presentation given by a manager at one of the lithium companies. In his discussion, he suggested that one of the impacts of brine extraction may be that the core part of the Salar can sink. When that happens, he informed the audience, water pools may appear at the edge of the Salar's core. Does our preliminary research, represented in the maps that show increased surface water, indicate that this is occurring in the Salar? The mapping workshop provided detailed narration of a range of environmental, climatic, social, political and economic change in the lives of people from Peine as a result of the growth of the extraction industries as well as other kinds of change that have produced the multidimensional conditions of exhaustion. People's narration of experience helps to disentangle the conjunctures of the ecological present to reveal particular actors that intersect to produce change. We argue in particular that an appreciation of people's experience with the Salar as a living and non-fixed entity - an 'unorthodox' environment - may assist in revealing the range of the Salar's particular conditions of exhaustion. This is significant because, despite very recent independent scientific attention (e.g. Liu et al. 2019) the Salar's ecological present is still a matter of fragmentation and disorder.

\section{Conclusions}

We began this article by considering the ways in which ecological exhaustion is the result of what Ferguson (2005) describes as extraction through 'territorialized' capital in which enclaves of productivity may be generated along with forms of disorder. In the case of the Salar, mining companies own, report on and extract within fragmented sections of the region as well as report on and create environmental models of isolated sectors. The manufacture of such enclaves of extraction, knowledge and (re)regulation has made the extent of environmental impact resulting from extraction of water by copper and lithium extraction companies difficult to discern over time. While the state has reached for greater regulatory powers for some years, it has only recently declared the environment exhausted, but nonetheless lacks scientific data about many ecological features of the Salar. A feature of ecological exhaustion in this case is, thus, disorder in knowledge rather than regulatory effects of state optics that seek and have the effect of presenting orderly, if not complete ecologies. This disorder in knowledge is a feature of the Salar's particular conditions of ecological exhaustion.

Moreover, considering the geochemical features of lithium mining that we discuss in this article, this extractive industry literally mines water. However, this water is not considered as mined by Chilean law. As we have indicated above, there are investigations into over-extraction on the Salar. However, the definition of water allows ongoing spaces of maneuver for the extractive industries; they continue exhausting water resources of the Salar arguing that it is not water, but brine. Thus regarding the lack of regulation around the impact of saltwater extraction, our initial findings indicated that there was increased surface water (as seen on the Figures). A simple interpretation of the images, only based on the remote sensing data, could lead us to conclude that water resources are increasing. However, examining the figures in the participatory workshop with Peineños led to a deeper understanding of the drastic shifts in people's lifeways associated with the extraction industry. Moreover, it revealed unorthodoxy in the Salar's surface water behavior that serves to emphasize the ways in which an ecology exhausted by extraction may reveal the unknown. We suggest that, at the very least, this should raise awareness of the need to further understand an environment subject to extraction in ways that are largely unregulated.

Exhaustion, by definition (using the terms of environmental economics), refers to the fact that more water is being extracted from the Salar than can possibly be regenerated. We argue that the conditions of ecological exhaustion caused by extractive industries may be far more complex than this apparently simple equation indicates. For people in Peine exhaustion can be extended to the impacts on their social, political and cultural lives. The conditions of exhaustion as territorialized disorder are reflected in public moral discourse, 
such as in the accusations by the President of Peine who refers to the "irresponsibility" of the authorities. Nonetheless, people's experiences of the Salar continue and are renewed within an exhausted environment. Using the maps as a lens through which change may be examined, people explained environmental change in ways that were layered with memory and lived experience. In turn, when politically situated, these memories have the potential to mobilize the recent past against injustice and dispossession and produce new trajectories in the relationships between people and their environment, with which they have been associated desde siempre (continually). As we have shown, one such trajectory is the Community of Peine's current resistance to new mining projects and strong positions against the growth of existing ones, as ever more extraction projects begin to appear in their territory.

\section{References}

Babidge, S. 2019. Sustaining ignorance: the uncertainties of groundwater and its extraction in the Salar de Atacama. Journal of the Royal Anthropological Institute 25(1): 83-102.

Bauer, C. 1998. Against the current: privatization, water markets, and the state in Chile. Boston, MA: Kluwer Academic.

Bauer, C. 2004. Siren song: Chilean water law as a model for international reform. Washington, DC: Resources for the Future.

Bebbington, A. and J. Bury. 2013. Political ecologies of the subsoil. In Bebbington, A. and J. Bury (eds.) Subterranean struggles: new dynamics of mining, oil, and gas in Latin America. Austin: University of Texas Press.

Bebbington, D.H. and D.G. Huber. 2017. Political settlements, natural resource extraction, and inclusion in Bolivia. Effective States and Inclusive Development Working Paper No. 77.

Blaikie, P. 1985. The political economy of soil erosion in developing countries. London: Longman.

Blaikie, P. and H.C. Brookfield. 1987. Land degradation and society. London: Methuen.

Box, J.B., A. Duguid, R.E. Read, R.G. Kimber, A. Knapton, J. Davis and A.E. Bowland. 2008. Central Australian waterbodies: the importance of permanence in a desert landscape. Journal of Arid Environments 72(8): 1395-1413. https://doi.org/10.1016/j.jaridenv.2008.02.022

Boyd, W., W.S. Prudham and R.A. Schurman. 2001. Industrial dynamics and the problem of nature. Society and Natural Resources 14(7): 555-570. https://doi.org/10.1080/08941920120686

Bridge, G. 2004. Contested terrain: mining and the environment. Annual Review of Environment and Resources 29(1): 205-259. https://doi.org/10.1146/annurev.energy.28.011503.163434

Budds, J. 2010. Water rights, mining and indigenous groups in Chile's Atacama. In Boelens, R., D. Getches and A. Guevara-Gil (eds.). Out of the mainstream: water rights, politics and identity. London: Earthscan. Pp. 197-211.

Camara de Diputados, Gobierno de Chile. 2016. Informe de la Comisión Especial Investigadora, de la participación de toda empresa u organismo público en la exploración, procesamiento, explotación, exportación y transporte de litio, así como de las características del contrato suscrito entre corfo y sqm para la explotación de dicho metal. Valparaiso, Chile. https://www.camara.cl/pdf.aspx?prmID=31700\&prmTIPO=INFORMECOMISION

Cámara de Diputados, Gobierno de Chile. 2017. Informe de la comisión especial investigadora de los actos de los organismos públicos competentes, encargados de la fiscalización y protección de glaciares, cuencas hidrográficas y salares de Chile. Report released 3/1/2017 (last accessed 23/12/2018).

Carruthers, D. 2001. Environmental politics in Chile: legacies of dictatorship and democracy. Third World Quarterly 22(3): 343-358. https://doi.org/10.1080/01436590120061642 
Cartajena, I., M.K. Núñez and L. Núñez. 2010. Phoenicopteridae exploitation in the Salar de Atacama Basin (3,000-2,200BP), Northern Chile. In Prummel, W., J.T. Zeiler and D.C. Brinkhuizen (eds.). Birds in archaeology: proceedings of the $6^{\text {th }}$ Meeting of the ICAZ Bird Working Group. Groningen: Barkhuis; Groningen University Library. Pp. 105-113.

Comisión Investigadora Acuerdo Corfo SQM. 2018. Audio-visual of Investigative Commission hearing 5/11/2018, available at: https://www.youtube.com/watch?v=5swpD4qtWgA

Comisión Chilena del Cobre [COCHILCO]. 2018. Anuario estadísticas del cobre y otros minerales 1998-2017. Santiago [Chile]: COCHILCO.

Cruikshank, J. 2005. Do glaciers listen? Local knowledge, colonial encounters, and social imagination. Vancouver: UBC Press.

Cruikshank, J. 2012. Are glaciers 'good to think with'? Recognising indigenous environmental knowledge. Anthropological Forum 22(3): 239-250. https://doi.org/10.1080/00664677.2012.707972

DeSilvey, C. 2016. Observed decay: telling stories with mutable things. Journal of Material Culture 11(3): 318338. https://doi.org/10.1177/1359183506068808

DGA. 2007. Nuevo texto que dispone normas de exploración y explotación de aguas subterráneas. Resolución 425, Santiago, 31 December 2007. Available at: https://www.leychile.cl/Navegar?idNorma=270521

DGA. 2012. Informe Técnico No324. Evaluación de la disponibilidad de recursos hídricos subterráneos en los sectores acuíferos del Salar de Atacama.

http://bibliotecadigital.ciren.cl/bitstream/handle/123456789/25994/HUM20116.pdf? sequence $=1$ \&is Allowed $=\mathrm{y}$

DGA. 2018. Zona de Prohibición sector hidrogeológico de aprovechamiento común C2 de la cuenca del Salar de Atacama. Norma Num.13 Santiago 22 June 2018. Available at https://www.leychile.cl/Navegar?idNorma=1121804

Dransart, P. 2002. Earth, water fleece and fabric: an ethnography and archaeology of Andean camelid herding. London: Routledge.

Espinoza, E. 1897. Jeografía descriptiva de la República de Chile: Arreglada segun las últimas divisiones administrativas, las más recientes esploraciones i en conformidad al Censo Jeneral de la República levantado el 28 de noviembre de 1895. Santiago: Imprenta i Encuadernación Barcelona.

Fairhead, J. and M. Leach. 1996. Misreading the African landscape society and ecology in a forest-savanna mosaic. Cambridge: Cambridge University Press.

Ferguson, J. 2005. Seeing like an oil company: space, security and global capitalism. American Anthropologist 107(3): 377-382.

Forsyth, T.J. 2002. Critical political ecology: The politics of environmental science. London: Routledge.

Frederiksen, T. 2019. Political settlements, the mining industry and corporate social responsibility in developing countries. The Extractive Industries and Society 6: 162-170. https://doi.org/10.1016/j.exis.2018.07.007

Head, L. 2017. Cultural landscapes and environmental change. London: Routledge.

Jacka, J. 2015. Alchemy in the rainforest: politics, ecology and resilience in a New Guinea mining area. Durham, NC: Duke University Press.

Jerez Henríquez, B. 2018. Impacto socioambiental de la extracción de litio en las cuencas de los salares altoandinos del cono sur. Santiago: Observatorio de Conflictos Mineros de América Latina, OCMAL. https://www.ocmal.org/impacto-sociambiental-litio/

Kalazich, F. 2013. Cultural meanings and values of the past: a participatory approach to archaeology in the Atacameño Community of Peine. PhD thesis, Institute of Archaeology. London: UCL.

Kalazich, F. 2015. Memory as archaeology: an experience of public archaeology in the Atacama Desert. Public Archaeology 14(1): 44-65. https://doi.org/10.1179/1465518715Z.00000000086

Kloppenburg, J.R. 1988. First the seed: the political economy of plant biotechnology, 1492-2000. Cambridge: Cambridge University Press. 
Lave, R., C. Biermann and S.N. Lane, 2018 Introducing critical physical geography. In Lave, R., C. Biermann and S.N. Lane (eds.). The Palgrave handbook of critical physical geography. London: Palgrave MacMillan. Pp. 3-21. link

Liu, W., D.B. Agusdinata and S.W. Myint. 2019. Spatiotemporal patterns of lithium mining and environmental degradation in the Atacama Salt Flat, Chile. International Journal of Applied Earth Observation and Geoinformation. 80: 145-156. https://doi.org/10.1016/j.jag.2019.04.016

Madaleno, I.M. and A. Gurovich. 2007. Usos conflictivos del agua en el norte de Chile. Boletín de la Asociación de Geógrafos Españoles 45: 353-372.

Magallanes, M.M. 1912. El camino del inca. Santiago: Imprenta Universitaria.

Moore, J. 2017. The Capitalocene, part 1: on the nature and origins of our ecological crisis. The Journal of Peasant Studies 44(3): 594-630.

Morrison, K.D. 2018. Empires as ecosystem engineers: toward a nonbinary political ecology. Journal of Anthropological Archaeology 52: 196-203.

Muñoz, S. 1894. Jeografía descriptiva de las provincias de Atacama i Antofagasta. Santiago: Imprenta Gutemberg.

Murray Li, T. 2014. Land's end: capitalist relations on an indigenous frontier. Durham, NC: Duke University Press.

Niemeyer, H. and M. Rivera. 1983. El camino del Inca en el despoblado de Atacama. Boletín de Prehistoria de Chile 9: 91-193.

Núñez, L. and C. Santoro. 1988. Cazadores de la puna seca y salada del área centro sur andina (norte de Chile). Estudios Atacameños 9: 13-65.

Núñez, L., I. Cartajena and C. Carrasco. 2008. Certificado de ocupaciones humanas. Unpublished manuscript in possession of the Community of Peine.

Núñez, M.K. 1998. Peine: saber andino, manejo de recursos y transformaciones. Estudios Atacameños 16: 283292.

Núñez, M.K. 2015. Sociedad, naturaleza y territorialidad en el desierto y puna de Atacama. Siglos XX - XXI. PhD Thesis, Universidad Catolica del Norte and Universidad de Tarapacá.

Philippi, R.A. 1860. Viage al desierto de Atacama hecho de orden del gobierno de Chile en el verano 1853-54. Santiago: Librería de Eduardo Anton.

Posey, D.A. 1985. Indigenous management of tropical forest ecosystems: the case of the Kayapó indians of the Brazilian Amazon. Agroforestry Systems 3: 139-158.

Prieto, M. 2015. Bringing water markets down to Chile's Atacama Desert. Water International 41: 191-212. https://doi.org/10.1080/02508060.2015.1107400

Prieto, M. 2016. Practicing costumbres and the decommodification of nature: the Chilean water markets and the Atacameño People. Geoforum 77: 28-39. https://doi.org/10.1016/j.geoforum.2016.10.004

Robbins, P. 2011. Political ecology: a critical introduction. Oxford: Blackwell.

Sanhueza, C. 2005. Espacio y tiempo en los límites del mundo, los Incas en el despoblado de Atacama. Boletín del Museo Chileno de Arte Precolombino 10(2): 51-77.

Servicio de Evaluación Ambiental. nd. (website of the Environmental Evaluation Service) www.sea.gob.cl, last accessed 28/5/2019.

Scott, J.C. 1998. Seeing like a state: how certain schemes to improve the human condition have failed. New Haven, CT: Yale University Press.

Toscano, A. 2018. Antiphysis/Antipraxis: universal exhaustion and the tragedy of materiality. Mediations 31(2): 125-144.

Troll, C. 1958. Las culturas superiores andinas y el medio geográfico. Revista del Instituto de Geografía 5. 
Vergara, T. 2018. Informe advierte de sobreexplotación en cuenca de agua clave para grandes mineras. El Mercurio [Santiago, Chile]. September 26 ${ }^{\text {th }}$, 2018: 14.

Von Tschudi, J.J. 1869. Reisen durch Südamerika, Band V. Leipzig: F.A. Brockhaus.

Watts, M.J. 1983. Silent violence: food, famine and peasantry in Northern Nigeria. Berkeley, CA: University of California Press.

Yager, K. 2015. Satellite imagery and community perceptions of climate change impacts and landscape change. In Barnes, J. and M. Dove (eds). Climate cultures: anthropological perspectives on climate change. New Haven, CT: Yale University Press. Pp. 146-168. 